\title{
STRATEGI PENINGKATAN IMPLEMENTASI ANGGARAN BERBASIS KINERJA PADA DITJEN ANGGARAN KEMENTERIAN KEUANGAN
}

\author{
Strategies for Increasing Implementation Performance Base Budgeting on Ministry of \\ Finance Directorate General of Budget
}

Yunus Ariwibawa1, Dwi Rachmina², A. Faroby Falatehan ${ }^{3}$

1 Staf Direktorat Jenderal Anggaran Kementerian Keuangan RI, Jakarta Pusat. Email: ariwibawakla10@gmail.com 2Staf Pengajar Pengajar Departemen Agribisnis, Fakultas Ekonomi dan Manajemen, IPB Email: dwirachmina@gmail.com

3Staf Pengajar Departemen Ekonomi Sumberdaya dan Lingkungan, Fakultas Ekonomi dan Manajemen, IPB.Email: f_falatehan@hotmail.com

\begin{abstract}
Performance-based budgeting is a system of planning, budgeting and evaluation that emphasizes the linkage between budget and desired outcomes. Budgeting with this performance approach is structured with output orientation. The performance achievements of the Ministry of Finance in 2015 on the implementation of the Ministry/Institution Budget Work Plan (RKA-K/L) only reached 91.24 percent.The accuracy of budget planning on the performance achievement of State Budget implementation at Directorate General of Budget in 2015 was 90.20 percent. Therefore, it is necessary to further improve the implementation of the performancebased budget formulation. Based on these conditions, the objective of this research is to formulate strategies in improving the implementation of performance-based budget at Directorate General of Budget. In the initial phase of this activity, the implementation of performance-based budgeting was measured. Following this, the factors in the implementation of performance-based budgeting were analyzed, and lastly, alternative strategies in an effort to improve the implementation of performance-based budgeting were formulated. In order to achieve these objectives, the methods used were (1) Likert scale to measure the implementation of performancebased budgeting; (2) IFE and EFE analyses were conducted to measure internal and external factors that are keys in performance-based budgeting, and (3) SWOT and QSPM analyses were carried out to formulate alternatives and determine key priority strategies.
\end{abstract}

Keywords: Performance-based Budgeting, Rating Scale, IFE, EFE, SWOT and QSPM

\begin{abstract}
ABSTRAK
Anggaran berbasis kinerja merupakan sistem perencanaan, penganggaran dan evaluasi yang menekankan pada keterkaitan antara anggaran dengan hasil yang diinginkan. Penganggaran dengan pendekatan kinerja ini disusun dengan orientasi output. Capaian Kinerja Kementerian Keuangan tahun 2015 atas pelaksanaan Rencana Kerja Anggaran Kementerian/Lembaga (RKA-K/L) hanya sebesar 91,24 persen. Akurasi perencanaan anggaran atas capaian kinerja pelaksanaan APBN pada Direktorat Jenderal Anggaran tahun 2015 sebesar 90,20 persen, Oleh karena itu perlu lebih ditingkatkan implementasi dalam menyusun anggaran berbasis kinerja. Berdasarkan pada kondisi tersebut, maka tujuan dilaksanakannya penelitian ini adalah untuk merumuskan strategi peningkatan implementasi anggaran berbasis kinerja pada Direktorat Jenderal Anggaran. Tahap awal dari kegiatan ini adalah mengukur implementasi anggaran berbasis kinerja. Selanjutnya dilakukan analisis faktor-faktor dalam implementasi anggaran berbasis kinerja, serta terakhir memformulasikan alternatif strategi dalam upaya peningkatan implementasi anggaran berbasis kinerja. Dalam rangka mencapai tujuan tersebut, metode yang digunakan yaitu (1) skala likert untuk mengukur implementasi anggaran berbasis kinerja; (2) analisis IFE dan EFE untuk mengukur faktor-faktor internal dan eksternal yang menjadi kunci dalam implementasi anggaran berbasis kinerja, dan (3) analisis SWOT dan QSPM untuk merumuskan alternatif dan menentukan strategi prioritas utama.
\end{abstract}

Kata kunci : Penganggaran Berbasis Kinerja, Rating Scale, IFE, EFE, SWOT dan QSPM

\section{PENDAHULUAN}

Pemerintah Indonesia melaksanakan reformasi dibidang pengelolaan keuangan
Negara dalam rangka mewujudkan good governance and clean government di bidang keuangan negara. Reformasi tersebut antara lain ditandai dengan diterbitkannya paket 
Undang Undang di bidang Keuangan Negara. Undang Undang Nomor 17 Tahun 2003 tentang Keuangan Negara, UndangUndang Nomor 1 Tahun 2004 tentang Perbendaharaan Negara dan UndangUndang Nomor 15 Tahun 2004 tentang Pemeriksaan Pengelolaan dan Tanggung Jawab Keuangan Negara serta UndangUndang Nomor 25 tahun 2004 tentang Sistem Perencanaan Pembangunan Nasional mengamanatkan Reformasi Sistem Perencanaan dan Penganggaran di Indonesia.

Bentuk Reformasi Manajemen Keuangan Pemerintah adalah penerapan tiga pendekatan penganggaran yaitu Anggaran Terpadu (Unified Budgeting), Anggaran Berbasis Kinerja (Performance Base Budgeting), dan Kerangka Pengeluaran Jangka Menengah (Medium Term Expenditure Framework). Ketiga pendekatan penganggaran tersebut harus diimplementasikan dengan baik untuk mewujudkan pengelolaan keuangan publik yang baik sebagai prasyarat terciptanya good governance and clean government $\mathrm{di}$ Indonesia.

Pendekatan penganggaran berbasis kinerja dianggap sebagai pendekatan yang paling utama dari ketiga pendekatan penganggaran tersebut. Penganggaran dengan pendekatan kinerja ini disusun dengan orientasi output. Jadi, apabila kita menyusun anggaran dengan pendekatan kinerja, maka mindset kita harus fokus pada "apa yang ingin dicapai". Kalau fokus ke "output", berarti pemikiran tentang "tujuan" kegiatan harus sudah tercakup di setiap langkah ketika menyusun anggaran. Penerapan pendekatan Anggaran Berbasis Kinerja (ABK) akan menghasilkan efisiensi, efektivitas, dan rasionalitas dalam pengelolaan anggaran. Dua pendekatan yang lain yaitu Unified Budgeting dan Medium Term Expenditure Framework merupakan bentuk implementasi bagi sempurnanya pelaksanaan anggaran berbasis kinerja. Penggunaan anggaran negara diharapkan akan lebih terarah, terukur, dan dapat dipertanggungjawabkan dengan Anggaran Berbasis Kinerja (ABK) sehingga fungsi pemerintahan dalam memberikan pelayanan kepada publik sesuai dengan prioritas pembangunan Nasional. Tugas terberat dalam reformasi pengganggaran adalah mengubah mindset dan paradigma para pengelola keuangan yang ada sekarang ini. Dimana seluruh Kementerian/Lembaga berupaya mendapat alokasi anggaran yang sebesar-besarnya tanpa dikaitkan dengan target kinerja yang dihasilkan.

Penganggaran berbasis kinerja ini berfokus pada efisiensi penyelenggaraan suatu aktivitas atau kegiatan. Efisiensi itu sendiri adalah perbandingan antara output dengan input. Suatu aktivitas dikatakan efisien, apabila output yang dihasilkan lebih besar dengan input, atau output yang dihasilkan adalah sama dengan input yang lebih sedikit. Anggaran ini tidak hanya didasarkan pada apa yang dibelanjakan saja, seperti yang terjadi pada sistem anggaran tradisional, tetapi juga didasarkan pada tujuan/rencana tertentu yang pelaksanaannya perlu disusun atau didukung oleh suatu anggaran biaya yang cukup dan terukur juga penggunaan biaya tersebut harus efisien dan efektif. Menerapkan penganggaran berbasis kinerja memang tidak semudah membalik telapak tangan, karena butuh proses dan upaya serius dari berbagai pihak terkait, khususnya kementerian/lembaga dan otoritas anggaran. Sebagai hal yang baru diterapkan di kementerian/lembaga, sangat wajar kalau masih ada kelemahan. Yang paling penting adalah upaya untuk terus berbenah agar penganggaran berbasis kinerja tidak melenceng dari filosofi dan tujuannya. Pengalaman negara lain yang sudah berhasil menerapkan anggaran kinerja, misalnya Australia, dapat menjadi contoh di Indonesia. Banyak aspek yang perlu dibenahi dalam penganggaran kinerja pada kementerian/lembaga, yaitu mencakup perencanaan kinerja, proses penyusunan dan pembahasan anggaran, format-format dokumen anggaran, sampai dengan pelaporannya. Terkait dengan perencanaan kinerja, Bappenas, 
Kementerian Keuangan dan Pada tahun 2009 Direktorat kementerian/lembaga perlu merestrukturisasi dan memetakan penamaan program dan kegiatan dalam Rencana Kerja Pemerintah (RKP), Rencana Kerja (Renja) dan Rencana Kerja Anggaran Kementerian/Lembaga (RKAKL) sehingga pendefinisian program lebih mencerminkan outcome pemerintah yang dapat dinikmati masyarakat dan berisi program-program yang menjadi core business masing-masing kementerian/lembaga. Direktorat Jenderal Anggaran telah melaksanakan amanat Undang-Undang Nomor 17 Tahun 2003 tentang Keuangan Negara mengenai penganggaran berbasis kinerja sejak awal. Dinamika sistem penganggaran berbasis kinerja selalu diikuti namun dalam pelaksanaannya ada berbagai kendala sehingga diperlukan langkah strategis dalam melihat keterkaitan antara Jenderal Anggaran telah melaksanakan restrukturisasi penganggaran dengan menyederhanakan program dan kegiatan, hasil penyederhanaan program tersebut yaitu Program Dukungan Manajemen, Program Peningkatan Sarana dan Prasarana dan Program Teknis Penganggaran. Restrukturisasi Program dan Kegiatan tersebut kurang berhasil karena pendanaan yang dikeluarkan kurang mencerminkan output/outcome yang dicapai. Pada tahun 2016 sistem penganggaran di Direktorat Jenderal Anggaran menerapkan Arsitekur Dasar Informasi Kinerja dengan konsep pendekatan Logic Model. Berdasarkan partisipasi penyampaian kinerja atas RKAKL tahun 2015 maka capaian kinerja Kementerian Keuangan belum optimal (Gambar 1).

pendanaan dengan keluaran.

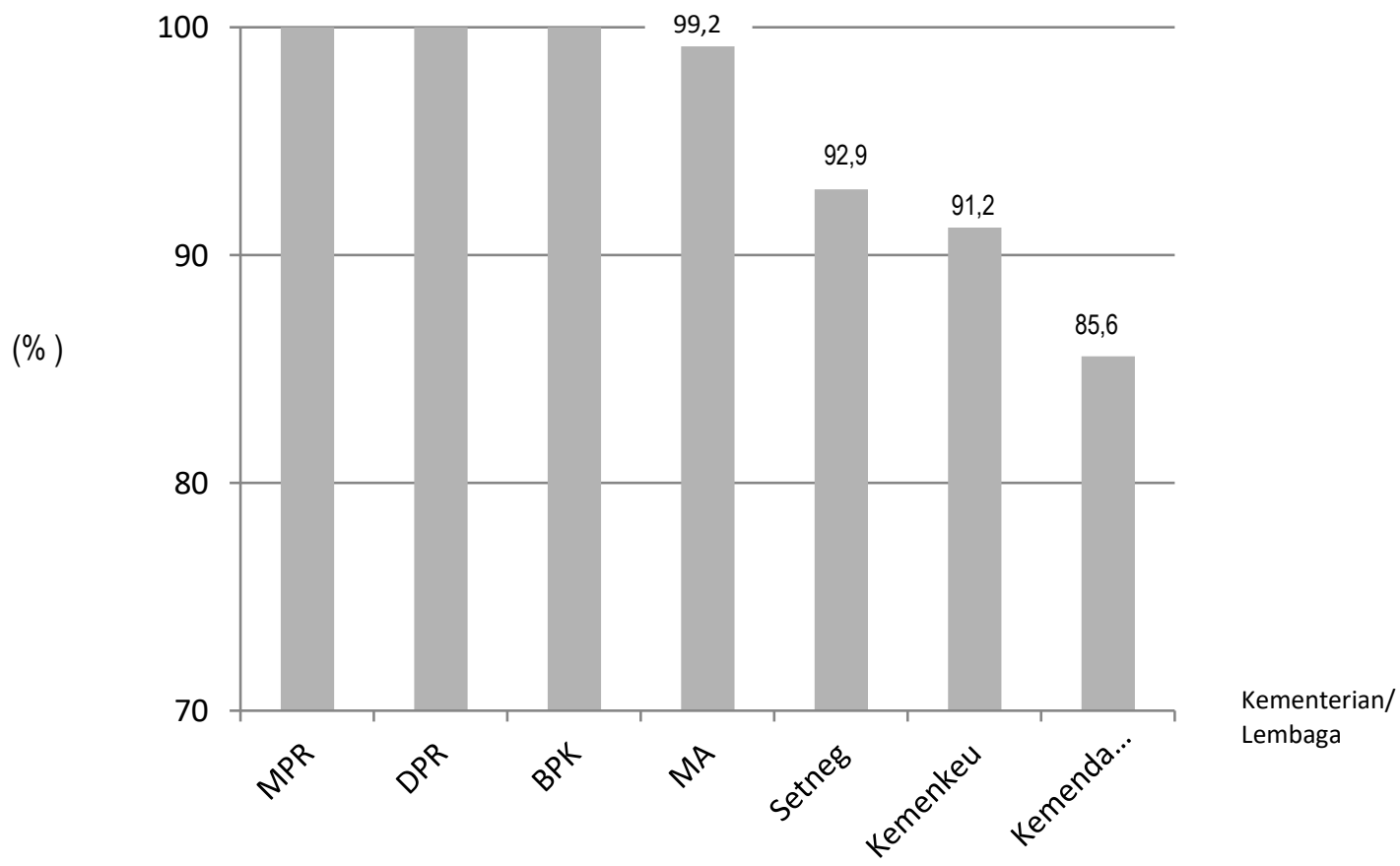

Sumber : Laporan Kinerja DJA, 2015

Gambar 1 Capaian kinerja RKA-KL tahun 2015

Capaian Kinerja Kementerian Keuangan tahun 2015 atas pelaksanaan RKA-K/L sebesar 91,2 persen. jika dibandingkan dengan capaian kinerja
Majelis Permusyawaratan Rakyat (MPR), Dewan Perwakilan Rakyat (DPR), Badan Pemeriksa Keuangan (BPK) dan 
Kementerian Pertahanan yang telah mencapai target $100 \%$.

Implementasi

penganggaran

terpadu, penganggaran berbasis kinerja dan kerangka pengeluaran jangka menengah sebagai kerangka konseptual dalam reformasi perencanaan dan penganggaran yang dimulai sejak tahun 2005 ternyata belum mampu diimplementasikan secara optimal. Hal ini menunjukkan bahwa masih terdapat permasalahan dalam pelaksanaan mekanisme perencanaan dan penganggaran. Konsep penganggaran berbasis kinerja belum dilaksanakan sepenuhnya sesuai dengan yang diharapkan serta pengalokasian anggaran ke dalam program kerja dan kegiatan kurang tepat

Tujuan dari penelitian ini adalah

untuk: 1) Mengukur implementasi anggaran berbasis kinerja Direktorat Jenderal Anggaran sebagaimana diamanatkan dalam pedoman dan kebijakan tentang perencanaan dan penganggaran; 2) Mengidentifikasi dan menganalisis faktorfaktor apa saja dalam implementasi anggaran berbasis kinerja di Direktorat Jenderal Anggaran; 3) Merumuskan Strategi peningkatan implementasi anggaran berbasis kinerja pada Direktorat Jenderal Anggaran.

\section{METODE PENELITIAN}

\section{Jenis dan Sumber Data}

Penelitian ini dilakukan di Direktorat Jenderal Anggaran Kementerian Keuangan, Lokasi berada di Jalan Wahidin No 1 Jakarta Pusat Provinsi Daerah
Khusus Ibu Kota Jakarta, Pengumpulan data dan bahan penelitian dilakukan pada bulan Februari sampai dengan Mei 2017. Data yang digunakan dalam penelitian adalah data primer dan data sekunder. Data Primer diperoleh dari observasi, wawancara mendalam, dan pengumpulan kuisioner yang dibagikan. Sementara itu data sekunder diperoleh dari buku-buku, jurnal dan peraturan-peraturan terkait.

\section{Metode Analisis Data}

Metode analisis yang digunakan sesuai dengan urutan tujuan dalam penelitian ini adalah: (1) Analisis kuantitatif dengan menggunakan skala likert; (2) Analisa kualitatif dengan wawancara mendalam; serta (3) Analisa Internal Factor Evaluation (IFE) dan External Factor Evaluation (EFE) untuk pemetaan kekuatan, kelemahan, peluang dan ancaman. Matrik Strenght - weakness - opportunities - threats (SWOT) untuk merumuskan prioritas strategi dan Matrik Quantitative Strategic Planning Matriks (QSPM) untuk menetapkan strategi utama.

\section{HASIL DAN PEMBAHASAN}

\section{Struktur Organisasi Direktorat Jenderal Anggaran}

Direktorat Jenderal Anggaran dipimpin oleh satu orang Direktur Jenderal setingkat eselon 1 (satu) yang dibantu oleh 8 (delapan) eselon II. Struktur organisasi Direktorat Jenderal Anggaran tersaji pada gambar 2 sebagai berikut : 


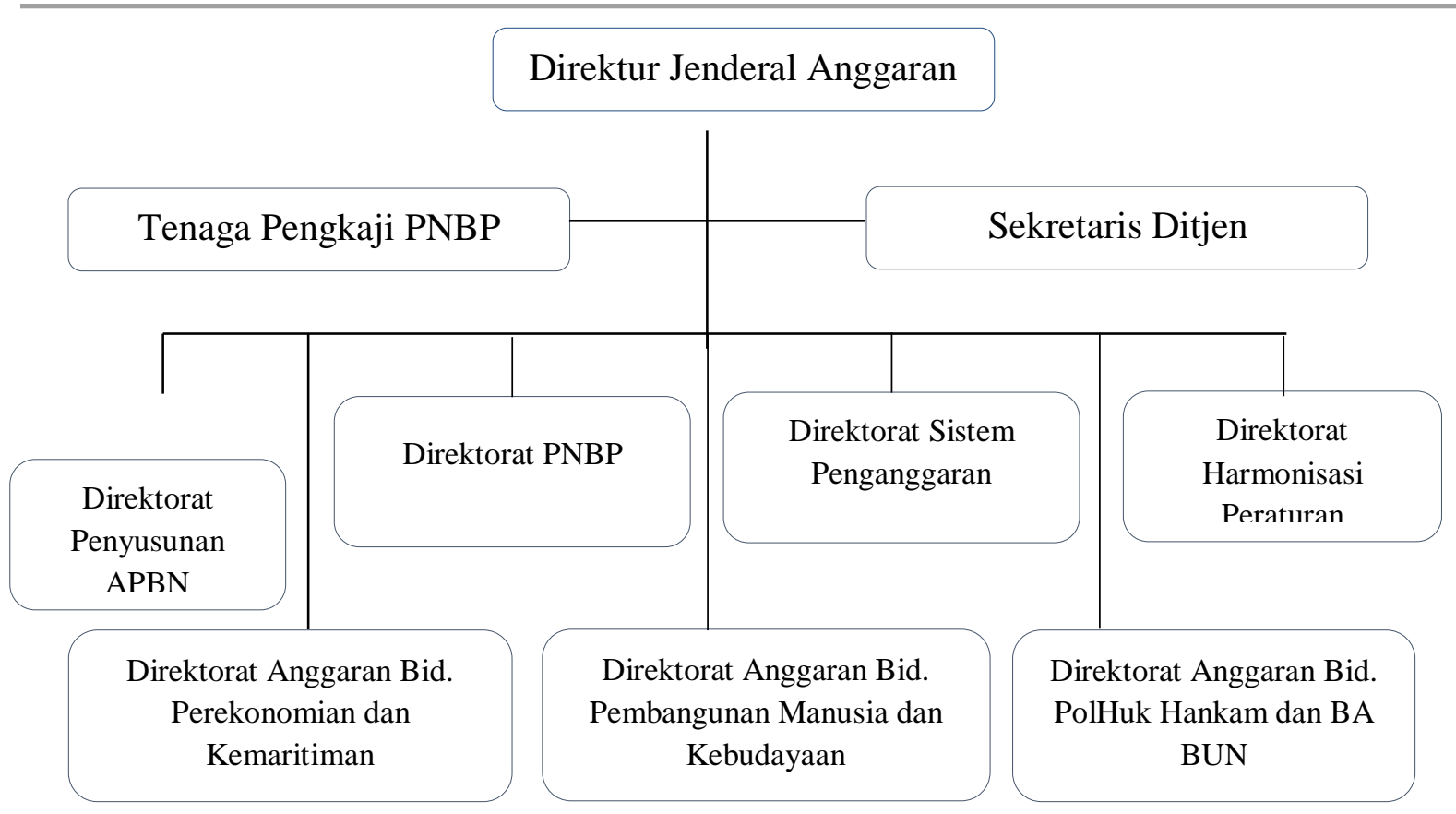

Sumber : Direktorat Jenderal Anggaran (2016)

Gambar 2 Struktur Organisasi Direktorat Jenderal Anggaran

\section{Karakteristik Responden}

Responden dalam penelitian ini sejumlah empat puluh lima orang terdiri dari /staf pengelola kegiatan, petugas pengelola administrasi belanja pegawai, pejabat pengadaan pengadaan barang dan jasa, dan pejabat penerima hasil pekerjaan di lingkungan Direktorat Jenderal Anggaran. Seluruh responden kedudukan dan jabatannya sesuai dengan Keputusan Direktur Jenderal Anggaran tentang Pejabat Kuasa Pengguna Anggaran/Pengguna Barang Direktorat Jenderal Anggaran.

\section{Uji validitas dan Uji Reabilitas}

\section{Uji validitas data}

Pengujian validitas dilakukan untuk menguji alat ukur atau kuesioner yang digunakan valid atau tidak valid dengan menggunakan korelasi product moment. Pengambilan keputusan valid atau tidaknya atribut berdasarkan nilai $r$ hitung dibandingkan dengan nilai $r$ tabel atau nilai probabilitas ( $\mathrm{p}$-value). Atribut dinyatakan valid bila koefisien korelasi (nilai r-hitung)
$>$ r-tabel atau nilai p-value $<0.05$. Adapun r-tabel untuk $n=45$ adalah 0.294. Dengan demikian seluruh r-hitung (koefisien korelasi) yang diperoleh dari hasil pengolahan data penelitian ini lebih dari rtabel..

\section{Uji Reliabilitas}

Uji reliabilitas yang akan digunakan dalam penelitian ini adalah dengan menggunakan SPSS, yakni dengan uji versi 23 statistik Cronbach Alpha (CA). Hasil pengujian reliabilitas terhadap seluruh indikator pada dimensi-dimensi yang digunakan dalam penelitian dapat diterima, demikian juga untuk keseluruhan tingkat pengukuran sesuai dengan yang dikemukakan oleh Idrus M. (2009). Metode penelitian sosial menyatakan bahwa suatu konstruk atau variabel dinyatakan reliabel jika nilai cronbach alpha > 0.60 (Idrus M. 2009). Berdasarkan uji reliabilitas nilai cronbach alpha untuk seluruh variabel lebih besar dari 0,60, Dengan demikian seluruh konstruk/variabel dinyatakan realibel.

\section{Implementasi Anggaran Berbasis Kinerja di Direktorat Jenderal Anggaran}


Tabel 1 Ikhtisar implementasi anggaran berbasis kinerja pada Direktorat Jenderal Anggaran

\begin{tabular}{|c|c|c|c|c|c|}
\hline No & Variabel & $\begin{array}{c}\text { Rata- } \\
\text { rata }\end{array}$ & $\begin{array}{l}\text { Skor } \\
\text { Ideal }\end{array}$ & TCR $(\%)$ & Kriteria \\
\hline 1 & $\begin{array}{l}\text { Kompetensi SDM Perencanaan dan } \\
\text { Penganggaran }\end{array}$ & 2.71 & 4 & 67.78 & Sedang \\
\hline 2 & Sarana Penunjang Anggaran Berbasis Kinerja & 2.86 & 4 & 71.44 & Sedang \\
\hline 3 & Penerapan Anggaran Berbasis Kinerja & 3.39 & 4 & 84.81 & Tinggi \\
\hline 4 & $\begin{array}{l}\text { Pelaksanaan Evaluasi terhadap Program dan } \\
\text { Kegiatan }\end{array}$ & 2.99 & 4 & 74.68 & Tinggi \\
\hline 5 & Penghargaan (reward) dan Sanksi (punishment) & 2.99 & 4 & 74.68 & Tinggi \\
\hline \multicolumn{2}{|c|}{ Total Implementasi Anggaran Berbasis Kinerja } & 2.99 & 4 & 74.68 & Tinggi \\
\hline
\end{tabular}

Tingkat implementasi anggaran berbasis kinerja di Direktorat Jenderal Anggaran sudah tinggi namun untuk kompetensi sumber daya manusia dan sarana penunjang masih masuk dalam kriteria sedang. Implementasi anggaran berbasis kinerja Direktorat Jenderal Anggaran ditentukan oleh kompetensi sumber daya manusia perencanaan dan penganggaran meliputi tingkat pendidikan, latar belakang pendidikan dan pengalaman/masa kerja.

\section{Strategi Peningkatan Implementasi Anggaran Berbasis Kinerja pada Direktorat Jenderal Anggaran Kementerian Keuangan}

Faktor yang menjadi kekuatan, kelemahan, peluang serta ancaman dalam implementasi anggaran berbasis kinerja diperoleh dari wawancara mendalam terhadap pakar/ahli dan kuisioner SWOT dan QSPM yang telah terkumpul (Tabel 2).

Tabel 2 Faktor kekuatan dan kelemahan dalam peningkatan implementasi angggaran berbasis kinerja pada Direktorat Jenderal Anggaran

\begin{tabular}{|c|c|c|c|c|}
\hline No & Kekuatan & Bobot & Rating & Skor \\
\hline 1 & $\begin{array}{l}\text { Kebijakan Organisasi dalam mendukung Implementasi } \\
\text { Anggaran Berbasis Kinerja (ABK) baik }\end{array}$ & 0.143 & 3.60 & 0.515 \\
\hline 2 & Data-data dalam penyusunan ABK dan Revisi lengkap & 0.125 & 3.40 & 0.425 \\
\hline 3 & $\begin{array}{l}\text { Peraturan Petunjuk Penyusunan ABK dan tata cara } \\
\text { revisi memadai }\end{array}$ & 0.111 & 3.80 & 0.422 \\
\hline 4 & Komitmen pejabat terkait Implementasi ABK tinggi & 0.106 & 3.60 & 0.380 \\
\hline \multicolumn{4}{|c|}{ Total Kekuatan } & 1.742 \\
\hline 1 & $\begin{array}{l}\text { Kelemahan } \\
\text { Aplikasi dalam mengimplementasikan ABK sulit dan } \\
\text { berubah-ubah }\end{array}$ & 0.104 & 1.80 & 0.188 \\
\hline 2 & Waktu penyusunan dan penelahaan RKA terlalu singkat & 0.090 & 1.40 & 0.126 \\
\hline \multirow{3}{*}{$\begin{array}{l}4 \\
5\end{array}$} & $\begin{array}{l}\text { Pelaksanaan monitoring dan evaluasi program dan } \\
\text { kegiatan tidak rutin }\end{array}$ & 0.068 & 1.40 & 0.095 \\
\hline & Tenaga fungsional perencana belum tersedia & 0.107 & 1.60 & 0.171 \\
\hline & $\begin{array}{l}\text { Komponen SDM bidang perencanaan dan anggaran } \\
\text { rendah }\end{array}$ & 0.146 & 1.60 & 0.233 \\
\hline & Total Kelemahan & & & 0.814 \\
\hline
\end{tabular}

Faktor kunci ekternal berdasarkan pengolahan data kuisioner diperoleh hasil sebagaimana tersaji pada Tabel 3 .
Pembuatan strategi harus menganalisis faktor faktor strategis organisasi (kekuatan, kelemahan, peluang, ancaman) 
pada situasi terkini. Pengumpulan data di lapangan yang dilakukan terhadap staf pengelola kegiatan /anggaran berupa pengisian kuisioner oleh responden dan wawancara mendalam dengan pejabat terkait pengelola kegiatan dan anggaran
Direktorat Jenderal Anggaran. Faktor kekuatan memperoleh skor terbesar yaitu 1.742, oleh sebab itu harus dioptimalkan untuk mencapai tujuan organisasi.

Tabel 3 Faktor peluang dan ancaman dalam peningkatan implementasi anggaran berbasis kinerja pada Direktorat Jenderal Anggaran

\begin{tabular}{clccc}
\hline No & \multicolumn{1}{c}{ Peluang } & Bobot & Rating & Skor \\
\hline 1 & $\begin{array}{l}\text { Kebijakan Nasional mengenai pemotongan anggaran } \\
\text { belanja barang dan perjalanan dinas sering } \\
\text { dilaksanakan }\end{array}$ & 0.111 & 3.00 & 0.333 \\
2 & $\begin{array}{l}\text { Peran dan Fungsi DJA dalam Trilateral Meeting } \\
\text { terbatas } \\
\text { Kebijakan Menpan RB terkait pengangkatan SDM } \\
\text { menjadi pejabat fungsional perencana belum tersedia }\end{array}$ & 0.217 & 2.67 & 0.1678 \\
\multicolumn{1}{c}{ Total Peluang } \\
\hline Ancaman & 3.67 & 0.611 \\
\hline No & $\begin{array}{l}\text { Peraturan mengenai penganggaran berbasis kinerja } \\
\text { lengkap dan jelas } \\
\text { BPPK memberi kesempatan untuk peningkatan } \\
\text { kapasitas aparatur perencanaan }\end{array}$ & 0.117 & 1.522 \\
\hline $\begin{array}{l}\text { Sekretaris Jenderal Kementerian Keuangan } \\
\text { memfasilitasi tambahan belanja operasional satker }\end{array}$ & 0.172 & 1.67 & 0.156 \\
\hline
\end{tabular}

Strategi intensif dan terintegrasi dalam peningkatan implementasi anggaran berbasis kinerja merupakan cara terbaik untuk saat ini. Untuk mencapai tujuan, tentu organisasi memerlukan sumber daya manusia. Agar sistem ini berjalan dengan baik tentu pengelolaan SDM harus memperhatikan program peningkatan kinerja secara kesinambungan dan dilakukan secara intensif. Beberapa aspek penting seperti sosialisasi, workshop, diklat perlu terus dipupuk dan ditingkatkan.

Mengacu pada tujuan peningkatan implemetasi anggaran berbasis kinerja dengan memperhatikan kekuatan, kelemahan, peluang dan ancaman yang ditemukan pada Direktorat Jenderal
Anggaran untuk selanjutnya dimasukkan pada matriks SWOT. Tujuan matriks ini adalah untuk memaksimalkan kekuatan dan peluang dan secara bersama-sama meminimalkan kelemahan dan acaman.

Dengan kata lain, matrik SWOT bertujuan untuk menggambarkan secara jelas bagaimana peluang dan ancaman eksternal dihadapi dengan memperhatikan kekuatan dan kelemahan yang di miliki oleh pengelola kegiatan dan keuangan pada Direktorat Jenderal Anggaran. Berdasarkan analisa SWOT dari faktor internal dan faktor eksternal terhadap faktor dalam implementasi anggaran berbasis kinerja di DJA dengan berbagai indikator penyusunnya, maka diperoleh beberapa alternatif strategi.

Tabel 4 Matriks SWOT Peningkatan Implementasi Anggaran Berbasis Kinerja pada Direktorat Jenderal Anggaran 


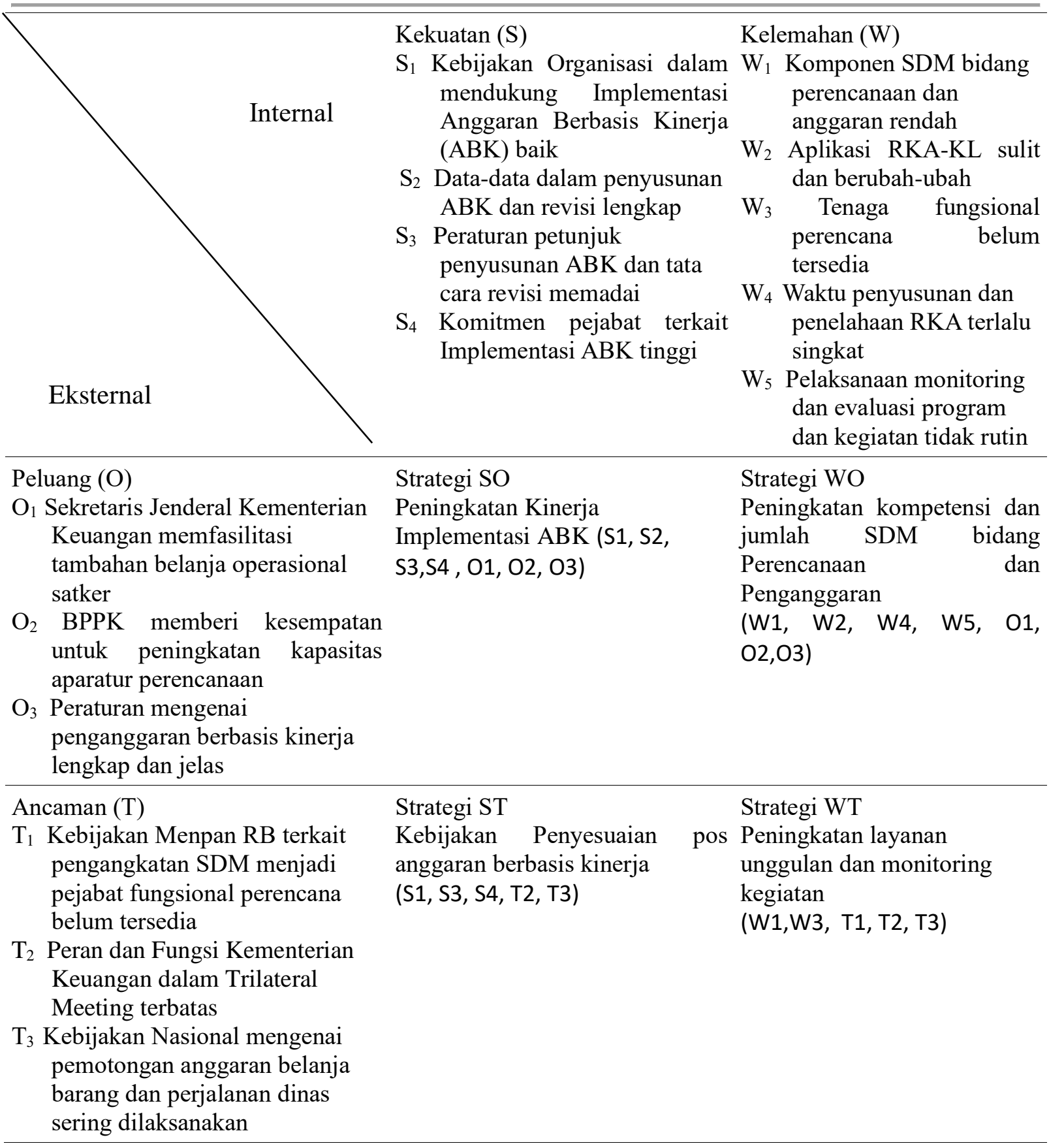

\section{Pemilihan Strategi}

Berdasarkan hasil pengolahan data matriks SWOT, diperoleh 4 (empat) strategi. Strategi tersebut disebarkan ke beberapa orang expert terkait, untuk memperoleh strategi prioritas. Para ahli tersebut diminta untuk membandingkan 4 grand strategy tersebut untuk diperingkatkan.dalam penetapan strategi yang benar-benar layak dan bisa implementasikan (grand strategy). Hasil data yang diperoleh diolah dengan menggunakan analisis QSPM (Quantitative Strategic Planning Matrix). Berdasarkan matrik QSPM diatas maka dapat disimpulkan jumlah nilai tertinggi atas TAS jatuh pada strategi Peningkatan Kompetensi dan Jumlah SDM bidang Perencanaan dan Penganggaran dengan nilai 7,5694. Hasil rumusan strategi prioritas ini sejalan dengan hasil kajian tujuan pertama dari tujuan kajian ini. Pada tujuan pertama telah menghasilkan kelemahan-kelemahan yang masih secara existing terjadi pada Kompetensi SDM bidang perencanaan/penganggaran.

\section{Perencanaan Implementasi Strategi}


Sebagai tindak lanjut dari hasil strategi utama yang sudah diperoleh dari analisis QSPM adalah melaksanakan strategi prioritas tersebut, untuk itu sangat perlu disusun rumusan strategi ke dalam bentuk pelaksanaan kebijakan operasional dalam bentuk pedoman atau acuan pelaksanaan strategi. Berdasarkan strategi utama yang telah dipilih maka dalam rangka peningkatan kualitas dan kuantitas SDM bagi pengelola kegiatan dan keuangan maka dapat dilaksanakan aktifitas/komponen sebagai berikut :

1. Rekrutmen SDM Pengelola Kegiatan dan Keuangan yang berkualitas

2. Pelaksanaan Wokshop dan Bimbingan Teknis Implementasi ABK

3. Penyesuaian besaran kompensasi bagi pengelola kegiatan dan keuangan.

\section{SIMPULAN DAN SARAN}

\section{Simpulan}

1. Tingkat implementasi anggaran berbasis kinerja di Direktorat Jenderal Anggaran sudah tinggi namun untuk kompetensi sumber daya manusia dan sarana penunjang masih masuk dalam kriteria sedang. Hal ini disebabkan :

a. Belum optimalnya sumberdaya manusia pengelola kegiatan dan anggaran dalam menerapkan standar operasional dan prosedur.

b. Pengembangan sumberdaya manusia dan kompetensi aparatur pengelola kegiatan dan anggaran yaitu pelatihan/kursus tentang perencanaan anggaran masih belum maksimal.

c. Tingkat pendidikan dan pengalaman kerja personil perencanaan dan penganggaran masih dalam perlu ditingkatkan.

d. Kurangnya ketegasan/ sanksi bagi aparatur pengelola kegiatan dan anggaran yang melakukan kesalahan.

2. Beberapa strategi yang dapat dilaksanakan dalam rangka peningkatan Implementasi Anggaran Berbasis Kinerja di DJA, antara lain rekrutmen
SDM pengelola kegiatan dan keuangan yang berkualitas, pelaksanaan workshop dan bimbingan teknis implementasi $\mathrm{ABK}$, penyesuaian kompensasi bagi pengelola kegiatan dan keuangan untuk meningkatkan semangat dan kompetensi kerja.

\section{Saran}

Direktorat Jenderal Anggaran dapat meningkatkan kompetensi sumberdaya manusia pengelola kegiatan dan anggaran melalui sosialisasi, bimbingan teknis dan pendidikan pelatihan dengan melibatkan Badan Pendidikan dan Pelatihan Keuangan ataupun Lembaga Pendidikan di luar. Penelitian mengenai implementasi ABK di DJA menggunakan metode penelitian Rating Scale, SWOT dan QSPM. Untuk perbaikan penelitian, diharapkan pada penelitian selanjutnya dapat menggunakan variabel, alat ukur, dan metode yang lain.

\section{DAFTAR PUSTAKA}

Arikunto S. 2010. Prosedur Penelitian: Suatu Pendekatan Praktik (Edisi Revisi) Jakarta: Rineka Cipta

Dwiputrianti S dan Suharsini. 2012. Analisis Penerapan Anggaran Berbasis Kinerja (ABK) terhadap Efisiensi, Efektivitas dan Akuntabilitas pada Puat Pendidikan dan Pelatihan Kementerian Dalam Negeri Regional Bandung. Jurnal Ilmu administrasi Volume IX Nomor 3, Desember 2012

David FR. 2012. Manajemen Strategis. Jakarta : Salemba Empat

Idrus M. 2009. Metode Penelitian Ilmu Sosial. Jakarta (ID) : Erlangga

Mardiasmo. 2009. Akuntansi Sektor Publik. Yogyakarta: Andi.

Rangkuti F. 2014. Analisis SWOT Teknik Membedah Kasus Bisnis. Jakarta :

PT. Gramedia Pustaka Utama, Sujarweni W, 2015. Akuntansi Sektor Publik. Pustaka Baru Press. Jogjakarta. 
Suparmoko. 2000. Keuangan Negara dalam teori dan praktek, edisi ke-5 Yogyakarta: BPFE

Singarimbun $M$ dan Soyfan, A.(Eds). 1995. Metode Penelitian Survai. Yogyakarta: LP3ES

Usman, Husaini dan Purnomo Setiady Akbar. 2008. Metodologi Penelitian Sosial, Jakarta: PT. Bumi Aksara

[UU] Undang Nomor 17 Tahun 2003 tentang Keuangan Negara,

[UU] Undang-Undang Nomor 1 tahun 2004 tentang Perbendaharaan Negara

[UU] Undang-Undang Nomor 15 Tahun 2004 tentang Pemeriksaan Pengelolaan dan Tanggung Jawab Keuangan Negara

[UU] Undang-Undang Nomor 25 tahun 2004 tentang Sistem Perencanaan Pembangunan Nasional

Verastera 2016. Pengaruh Anggaran Berbasis Kinerja terhadap Kinerja Aparatur Pemerintah Daerah (Studi Kasus pada Dinas Sosial Provinsi Jawa Barat). Jurnal Manajemen, Volume 15 Nomor 2, Mei 2016. 